\title{
REVIEW
}

\section{Energy Balance and Significance of Micro- Organisms in a Kelp Bed Community}

\author{
R. C. Newell ${ }^{1}$, J. G. Field ${ }^{2}$ and C. L. Griffiths ${ }^{2}$ \\ ${ }^{1}$ Institute for Marine Environmental Research, Prospect Place, Plymouth PL1 3DH, United Kingdom \\ ${ }^{2}$ Department of Zoology, University of Cape Town, Rondebosch 7700, South Africa
}

\begin{abstract}
Primary production by phytoplankton in a Benguela upwelling region off the west coast of the Cape Peninsula, South Africa, is almost equal to that within beds of the kelps Ecklonia maxima and Laminaria pallida. Total primary production of kelps, understorey algae and phytoplankton within an idealised kelp bed of $10 \mathrm{~m}$ average depth is $62,190 \mathrm{~kJ} \mathrm{~m}^{-2} \mathrm{yr}^{-1}$, as compared to $54,037 \mathrm{~kJ} \mathrm{~m}^{-2} \mathrm{yr}^{-1}$ for the phytoplankton community in deeper water nearby. The overall energetic conversion from incident illumination is $1.7 \%$ within the kelp bed and $1.5 \%$ for phytoplankton in the nearby water column, suggesting that a net production efficiency of 1.5 to $1.7 \%$ may approach the maximum attainable by aquatic plants under conditions where nutrients are rarely limiting. The fauna is dominated by filter feeders, which are responsible for $72 \%$ of total animal standing stock (B), $77 \%$ of total production (P), $94 \%$ of respiration (R), $84 \%$ of consumption (C) and $89 \%$ of faecal production ( $F$ ). Independent estimates of primary production and energy requirements of consumers balance to within $8 \%$, lending confidence to the calculations. Suspended matter, the food of filter feeders, is comprised of macrophyte particles, animal faeces and phytoplankton in roughly equal proportions. Bacteria which utilise dissolved and particulate components of fragmented macrophytes and faeces may produce up to $6,403 \mathrm{~kJ} \mathrm{~m}^{-2} \mathrm{yr}^{-1}$, which is small energetically but belies their importance in protein enrichment of food and in nutrient cycling. The kelp community appears to depend primarily on rapid bacterial mineralisation of fragmented kelp and faeces to recycle the minerals necessary to sustain primary production, supplemented by bouts of upwelling.
\end{abstract}

\section{INTRODUCTION}

The significance of micro-organisms both in the mineralisation of organic debris from a variety of sources and as potential food for consumer organisms has been widely recognised (Darnell, 1967; Mann, 1972; Odum et al., 1973; Odum and Heald, 1975; Cammen et al., 1978; Cammen, 1980a,b). Estimates of the efficiency of assimilation of micro-organisms by consumers, for example, range between 40 and $90 \%$ (Zhukhova, 1963; Fenchel, 1970; Hargrave, 1970; Kostalos, 1971; Calow and Fletcher, 1972; Chua and Brinkhurst, 1973; Calow, 1975; Kofoed, 1975a; Wetzel, 1975; Moriarty, 1976; Yingst, 1976; Lopez et al., 1977; Cammen et al., 1978), whilst net assimilation of inert structural components of detritus is commonly less than 10\% (Hargrave, 1970; Calow, 1975; Alexander,
1976; Wetzel, 1977; Cammen et al., 1978). Partly for these reasons, it has been generally accepted that plant detritus may be first colonised by microbial decomposer organisms before it becomes suitable as food for consumers. The microbiota may then be stripped from the inert detrital particles, which are subsequently returned to the environment for further microbial colonisation (Newell, 1965; Fenchel, 1970, 1972; Odum and Heald, 1975; Wetzel, 1975; Berrie, 1976; Hargrave, 1976; Yingst, 1976; Lopez et al., 1977; Taghon et al., 1978). Estimates of the amounts of bacterial carbon available to consumer organisms via this decomposer pathway have, however, differed widely and until recently there have been few detailed attempts to determine whether the absorption of microbial carbon could quantitatively match the estimated carbon requirements of consumers. 
Most recent studies on the role of bacteria in the nutrition of deposit feeders have reported that the quantity of bacteria consumed is substantially less than the carbon requirements of the organisms (Baker and Bradnam, 1976; Wetzel, 1977; Jensen and Siegismund, 1980). Again, Cammen et al. (1978) and Cammen $(1980 \mathrm{a}, \mathrm{b})$ have pointed out that bacterial carbon is generally only 1 to $3 \%$ of total sediment organic carbon (Dale, 1974; Rublee et al., 1978; Sorokin, 1978; Kepkay and Novitsky, 1980). The annual consumption of microbial carbon by the deposit-feeding polychaete Nereis succinea is thus calculated to be $5.2 \mathrm{~g} \mathrm{~m}^{-2}$ whilst the absorption efficiency is $57 \%$; absorbed carbon from the micro-organisms is thus $2.96 \mathrm{~g} \mathrm{~m}^{-2} \mathrm{yr}^{-1}$. Carbon incorporation into production plus losses through respiration, however, were $11.59 \mathrm{~g} \mathrm{~m}^{-2} \mathrm{yr}^{-1}$. The complete carbon budget for $N$. succinea thus suggests that only $2.96 / 11.59=25.5 \%$ of its carbon requirements could be met by utilisation of microbial carbon. Even if absorption of microbial carbon were complete, this resource could only meet $45 \%$ of estimated carbon requirements. Cammen et al. (1978) and Cammen (1980b) thus suggested that some of the carbon necessary to balance the budget may come from direct utilisation of plant debris. They cited evidence that some invertebrates have the enzymes necessary to utilise cellulose directly (Yokoe and Yasumasu, 1964; Lewis and Whitney, 1968; Forster and Gabbott, 1971; Elyakova, 1972; Kristensen, 1972) and pointed out that even if absorption efficiency from detritus itself was low, sufficient material may be processed to allow the carbon budget to be balanced.

An alternative method of assessing the trophic significance of micro-organisms is to estimate the microbial production from detrital decomposition and calculate the extent to which the total energy requirements of consumer organisms can be met by utilisation of this food resource (see also Steele, 1974; Mills, 1975; Mills and Fournier, 1979). There is now fairly detailed information on primary production (Field et al., 1977 , Dieckmann, 1978, 1980; Mann et al., 1979; Jarman, 1981; summarised in Newell et al., 1980), standing stocks (Velimirov et al., 1977; Field et al., 1980b), and consumption requirements of organisms associated with kelp beds of the west coast of the Cape Peninsula, South Africa. There is also information on microbial carbon conversion of kelp debris in non-enriched local seawater (Linley and Newell, 1981; Linley et al., 1981; Lucas et al., 1981; Newell, 1982; Newell and Lucas, 1981; Stuart et al., 1981, 1982), Comparable results have been obtained in the field in a microcosm experiment (Koop et al., 1982).

It is the purpose of this paper to synthesise the information on both production and population energy requirements for the kelp bed community. The evi- dence suggests that even though total primary production from macrophytes and nearshore phytoplankton is comparable with phytoplankton production in a nearby upwelling area, the combined microbial and phytoplankton food resources of the kelp bed are insufficient to meet more than $50 \%$ of the calculated consumption of the community as a whole. Consumer organisms thus appear to be dependent for about half of their energetic requirements on direct utilisation of detrital material, much as has been reported for individual members of deposit-feeding communities.

\section{PRIMARY PRODUCTION BY THE KELP BED COMMUNITY}

Primary production by marine macrophytes has been compared with that of phytoplankton by Mann (1972, 1973). He found that primary production by the seaweeds in St. Margaret's Bay, Nova Scotia greatly exceeded that of phytoplankton in the open waters of the bay itself, even though the area occupied by phytoplankton greatly exceeded that colonized by macrophytes. From this we might expect the relative contribution by macrophytes to the detrital pool in coastal areas to be high compared with that from phytoplankton. In areas on the western Cape coast, however, upwelling occurs in and immediately outside the kelp beds during much of the year and here the relative contribution by macrophytes and phytoplankton may be very different from that in areas where phytoplankton production is limited by nutrient availability. It is therefore of interest to compare total primary production by all components of the kelp bed system, with that of phytoplankton in the adjacent upwelling area.

The major components of primary production in kelp beds are the kelps and their associated epiphytes, understorey algae and phytoplankton. For the purposes of energy-flow calculations, we have taken a typical kelp bed off the southern Cape Peninsula as being represented by $10 \mathrm{~km}$ coast $\times 500 \mathrm{~m}$ width (i.e. to approximately $20 \mathrm{~m}$ depth line) of average depth $10 \mathrm{~m}$, derived from data given by Field et al. (1980b).

\section{Macrophyte Production}

The dominant macrophytes in South African kelp beds are Laminaria pallida and Ecklonia maxima, with occasional Macrocystis angustifolia. To these should be added the understorey algae, comprising mainly Botryocarpa prolifera, Neuroglossum binderianum, Pachymenia carnosa, Trematocarpus spp., and Hymenena venosa, and kelp epiphytes. The latter occur mainly on E. maxima and comprise Carpob- 
Table 1. Biomass $\left(\mathrm{B}, \mathrm{g}\right.$ wet weight $\mathrm{m}^{-2}$ ) frond $\mathrm{P} / \overline{\mathrm{B}}$ ratios and production $(\mathrm{P})$ of principal components of a typical kelp bed on the west coast of Cape Peninsula, South Africa. Production values expressed as wet mass, dry mass and carbon $\left(\mathrm{g} \mathrm{m}^{-2} \mathrm{yr}^{-1}\right)$ and energy equivalents $\left(\mathrm{kJ} \mathrm{m}^{-2} \mathrm{yr}^{-1}\right)$

\begin{tabular}{|c|c|c|c|c|c|c|c|}
\hline \multirow[t]{2}{*}{ Source } & \multicolumn{2}{|c|}{ Biomass } & \multirow{2}{*}{$\begin{array}{l}\text { Frond } \\
P / B\end{array}$} & & \multicolumn{3}{|c|}{ Annual production } \\
\hline & Total & Frond & & Wet & Dry & Carbon & Energy \\
\hline Ecklonia maxima & 3,492 & 1,746 & 4 & 6.983 & 1,041 & 306 & 16,559 \\
\hline Epiphytes & 262 & 262 & 4 & 1,047 & 156 & 34 & 2,416 \\
\hline Laminaria pallida & 2,307 & 1,154 & 4 & 4,587 & 573 & 144 & 6,273 \\
\hline Understorey & 998 & 998 & 4.2 & 4,166 & 946 & 255 & 11,586 \\
\hline Total growth & 7,059 & 4,160 & - & 16,783 & 2,716 & 739 & 36,834 \\
\hline $\begin{array}{l}\text { Kelp mortality in storms } \\
(12 \% \text { of biomass })\end{array}$ & - & - & - & 696 & 97 & 28 & 1,370 \\
\hline Total macrophyte production & & & & 17,479 & 2,813 & 767 & 38,204 \\
\hline
\end{tabular}

lepharus flaccida, Carradoria virgata and Suhria vittata, which together add approximately $7.5 \%$ to the wet biomass of the host (Allen and Griffiths, 1981). The relative proportions of the standing crop of the 2 major kelp species and of the understorey algae are shown in Table 1 and are based on the mean data for a series of transects on the west coast of South Africa (Field et al., 1980 b). Macrophyte biomass values are based on data for Oudekraal and Kommetjie (Field et al., 1980b). Frond production values for the kelp are based on data from Field et al. (1977, 1980b), Dieckmann (1978, 1980), Mann et al. (1979) and Jarman and Carter (1982). For the purposes of calculation, we have assumed the P/B ratio for epiphytes to be the same as that for the frond of their host. Production values for understorey algae were estimated from R. Anderson (University of Cape Town, pers. comm.).

Jarman and Carter (1982) have estimated that approximately $12 \%$ of the standing stock of kelp (stipes plus fronds) is lost annually in storms. Mortality thus adds some $1,370 \mathrm{~kJ} \mathrm{~m}^{-2} \mathrm{yr}^{-1}$ to the production of the kelp fronds (Table 1).

It is evident that total primary production by the macrophytes amounts to $38,204 \mathrm{~kJ} \mathrm{~m}^{-2} \mathrm{yr}^{-1}$, of which the understorey algae contribute $11586 / 38204=30 \%$. Frond production by Ecklonia maxima plus its epiphytes comprises a further $18975 / 38204=50 \%$ of the total, Laminaria pallida frond production contributes $16 \%$, with storm mortality of whole kelps making up the remaining $4 \%$. These values have been used to quantify the pathways of energy flow through the kelp bed community as shown in Fig. 1.

\section{Phytoplankton Production}

A range of values for phytoplankton production have been summarised in the well known paper by Ryther

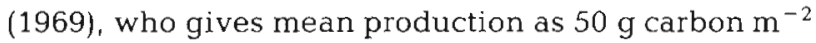
$\mathrm{yr}^{-1}$ for open ocean, $100 \mathrm{~g} \mathrm{C} \mathrm{m}^{-2} \mathrm{yr}^{-1}$ for coastal zones and $300 \mathrm{~g} \mathrm{C} \mathrm{m}^{-2} \mathrm{yr}^{-1}$ for upwelling areas. Within a kelp bed itself, primary production per unit area is limited both by depth and the shading effect of macrophytes (Borchers and Field, 1981) and possibly by nutrient availability. Carter" (in press) has recently measured phytoplankton production at the outer edge of a kelp bed at Oudekraal, on the west coast of the Cape Peninsula, and estimated mean annual production at $57 \mathrm{~g} \mathrm{C} \mathrm{m}^{-3}$, a value which coincides with the average for deeper waters outside the kelp bed (Brown, 1981). Using a conversion ratio of $47.82 \mathrm{~kJ} \mathrm{~g}$ carbon $^{-1}$ (Platt and Irwin, 1973) this yields a phytoplankton production value of $27,257 \mathrm{~kJ} \mathrm{~m}^{-2} \mathrm{yr}^{-1}$. Borchers and Field (1981) estimated that the shading effect of kelp reduced phytoplankton by approximately $12 \%$ over the whole kelp bed. Primary production by the phytoplankton component in the kelp bed is thus reduced to $23,986 \mathrm{~kJ} \mathrm{~m}^{-2} \mathrm{yr}^{-1}$ by the combined effects of shallow depth and shading by macrophytes, a value comparable with the frond production of $25,248 \mathrm{~kJ} \mathrm{~m}^{-2}$ $\mathrm{yr}^{-1}$ of the kelp plus epiphytes (Table 1).

In contrast, Brown $(1980,1981)$, using the oxygen light-dark bottle technique, has shown primary production at an active upwelling site off kelp beds at Oudekraal to be $823 \mathrm{~g} \mathrm{C} \mathrm{m}^{-2} \mathrm{yr}^{-1}$, although in an adjacent area at Robben Island, which has a more stable water column influenced by nearby upwelling. primary production reaches a remarkable $1,432 \mathrm{~g} \mathrm{C}$

\footnotetext{
- Carter estimates that the net phytoplankton primary production in a $20 \mathrm{~m}$ water column at the edge of the kelp bed is $1.129 \mathrm{~kg} \mathrm{C} \mathrm{m}{ }^{-2} \mathrm{yr}^{-1}$ and that most production occurs when the water column is stratified in the top $10 \mathrm{~m}$. Thus our value for the whole kelp bed may appear to be an underestimate. However, Field et al. (1980a) have shown that phytoplankton concentrations in shallow water within the kelp bed are some $50 \%$ lower than at the outer edge, justifying our estimate
} 
$\mathrm{m}^{-2} \mathrm{Yr}^{-1}$. These estimates were obtained by integrating values down to the $1 \%$ light level or the depth of mixing, whichever was the shallower. Her best estimate of primary production in the water column over the Southern Benguela region is given as $1,130 \mathrm{~g} \mathrm{C}$ $\mathrm{m}^{-2} \mathrm{yr}^{-1}$, or $54,037 \mathrm{~kJ} \mathrm{~m}^{-2} \mathrm{yr}^{-1}$.

This value may now be compared with the sum of primary production by phytoplankton and macrophytes in the shallow waters of the kelp bed. From p. 105 we obtain a value of $23,986 \mathrm{~kJ} \mathrm{~m}^{-2} \mathrm{yr}^{-1}$ for kelp bed phytoplankton, $11,586 \mathrm{~kJ} \mathrm{~m}^{-2} \mathrm{yr}^{-1}$ for understorey algae, and $26,618 \mathrm{~kJ} \mathrm{~m}^{-2} \mathrm{yr}^{-1}$ for kelp plus epiphytes. This yields a total production of $62,190 \mathrm{~kJ} \mathrm{~m}^{-2} \mathrm{yr}^{-1}$ for the kelp bed which is similar to the value of $54,037 \mathrm{~kJ}$ $\mathrm{m}^{-2} \mathrm{yr}^{-1}$ for phytoplankton production in a deeper water column. This suggests that the high primary production of macrophytes compensates for the reduced phytoplankton production in the shallow waters of the keip bed, but equaliy shows that phyioplankton production in upwelling areas, where nutrients are rarely limiting, may approach the value of total primary production in the seaweed zone and considerably exceed that of the macrophytes themselves.

It is also of interest to calculate the net production efficiency of the kelp bed producers compared with the phytoplankton nearby. Professor R. F. Fuggle (School of Environmental Studies, University of Cape Town) has kindly supplied us with data for photosynthetically active radiation (P.A.R.) measured over a 10 -yr period near Cape Town and representative of the incident energy on the kelp beds. The data yield an average value of $3,608 \times 10^{3} \mathrm{~kJ} \mathrm{~m}^{-2} \mathrm{Yr}^{-1}$ so that net production efficiency for the phytoplankton is $54,037 / 3,608,000=$ $1.5 \%$ and for the kelp bed community is $62,190 / 3,608,000$ $=1.7 \%$. These values are similar to those obtained by Teal (1962) who found a net production efficiency of $1.3 \%$ for a Georgia salt marsh, where the radiation was $2.508 \times 10^{3} \mathrm{~kJ} \mathrm{~m}^{-2} \mathrm{yr}^{-1}$. The similarity of the values for phytoplankton, kelp beds and saltmarshes suggests that a natural net production efficiency of $1.5-1.7 \%$ may approach the maximum attainable by plants under aquatic conditions when nutrients are rarely limiting.

\section{SECONDARY PRODUCTION BY THE KELP BED COMMUNITY}

The data for standing stock $\left(\mathrm{kJ} \mathrm{m}^{-1}\right)$ of the principal consumer organisms in an idealised kelp bed typical of the west coast of the Cape Peninsula are summarised in Table 2. The standing stock data have been derived from Velimirov et al. (1977); values for Production (P), Respiration (R), Consumption (C) and Faeces (F), determined for key components of the fauna for each trophic level, have been assumed for the group as a whole.

\section{Grazers}

One characteristic feature of the kelp bed community of the Cape Peninsula, is that herbivores directly utilising living kelp as a food resource are scarce. The dominant grazer is the sea urchin Parechinus angulosus, which has a mean biomass equivalent to $258 \mathrm{~kJ} \mathrm{~m}^{-2}$. The gastropods Haliotis midae and Patella spp. account for 20 and $14 \mathrm{~kJ} \mathrm{~m}^{-2}$ respectively, whilst the remaining herbivores make up only $8 \mathrm{~kJ} \mathrm{~m}^{-2}$. The standing stock of grazers as a whole is thus $300 \mathrm{~kJ} \mathrm{~m}^{-2}$, or only $4.17 \%$ of that of consumer organisms as a whole.

No information is available on the energetics of Haliotis midae or the Patella spp. Which utilise the kelp, but Greenwood (1980) has derived an energy budget for Parechinus angulosus, which comprises $86 \%$ of the grazer component. He reported a ratio of $\mathrm{P} /$ $\mathrm{B}$ of 1.04 and $\mathrm{C} / \mathrm{B}$ of 15.5 ; hence grazer production is $312 \mathrm{~kJ} \mathrm{~m}^{-2} \mathrm{yr}^{-1}$ and consumption $4,650 \mathrm{~kJ} \mathrm{~m}^{-2} \mathrm{yr}^{-1}$. Respiration (R) and faecal losses (F) are 1,083 and $1,588 \mathrm{~kJ} \mathrm{~m}^{-2} \mathrm{yr}^{-1}$ respectively. Since Consumption (C) $=$ Production $(\mathrm{P})+$ Respiration $(\mathrm{R})+$ Faeces $(\mathrm{F})+$ Dissolved organic matter (U) the energy budget for the grazers as a whole is:

$$
\begin{aligned}
& \mathrm{C}-(\mathrm{P}+\mathrm{R}+\mathrm{F})=\mathrm{U} \\
& \text { Or } 4,650-(2,983)=1,667 \mathrm{~kJ} \mathrm{~m}^{-2} \mathrm{Yr}^{-1}
\end{aligned}
$$

It is thus evident that the energy budget for herbivores based on data for urchins contains a relatively large component, amounting to as much as $36 \%$ of (C) which possibly represents dissolved losses (U). It is also apparent that the grazing component, which is dominated by urchins, has a relatively low $\mathrm{P} / \mathrm{C}$ ratio of $6.7 \%$, much of the energy consumed being dissipated through respiration $(R)$ faeces $(F)$ and as $(U)$ (see also Table 4).

\section{Filter Feeders}

The filter-feeding component dominates the kelp bed fauna with a standing stock equivalent to $5,155 \mathrm{~kJ}$ $\mathrm{m}^{-2}$ or $71.8 \%$ of the total. The mussel Aulacomya ater represents $45.7 \%$ of this component, sponges (Tethya sp.) $12.5 \%$ and ascidians (Pyura sp.) $5.7 \%$. The residual $36 \%$ comprises a variety of other, smaller filter feeders. A good deal is now known of the filtration rate, absorption efficiency, respiration and production of A. ater (Griffiths and King, 1979a, b), both in relation to food availability and body size. It is therefore possible to make some fairly detailed estimates of 
Table 2. Standing stock $\left(\mathrm{kJ} \mathrm{m}^{-2}\right)$ and energy budgets $\left(\mathrm{kJ} \mathrm{m}^{-2} \mathrm{yr}^{-1}\right)$ of the fauna of an idealised kelp bed on the west coast of Cape Peninsula, South Africa. Standing stock values derived from Velimirov et al. (1977). Energy budgets for grazers based on data for Parechinus angulosus (Greenwood, 1980), for suspension feeders on data for Aulacomya ater (Griffiths and King, 1979a, b) and Pyura stolonifera (Fitzgerald, 1979), and for carnivores on data for Jasus lalandii and Cirolana imposita (Humphreys, 1979; Shafir and Field, 1980)

\begin{tabular}{|c|c|c|c|c|c|}
\hline Component & $\begin{array}{l}\text { Standing stock } \\
\text { (B) }\end{array}$ & $\begin{array}{l}\text { Production } \\
\text { (P) }\end{array}$ & $\begin{array}{l}\text { Respiration } \\
\text { (R) }\end{array}$ & $\begin{array}{c}\text { Consumption } \\
\text { (C) }\end{array}$ & $\begin{array}{l}\text { Faeces } \\
(F)\end{array}$ \\
\hline \multicolumn{6}{|l|}{ Grazers } \\
\hline Parechinus angulosus & 258 & & & & \\
\hline Haliotis midae & 20 & & & & \\
\hline Patella spp. & 14 & & & & \\
\hline Others & 8 & & & & \\
\hline Sub-total & 300 & 312 & 1,083 & 4,650 & 1,588 \\
\hline \multicolumn{6}{|l|}{ Filter feeders } \\
\hline Aulacornya ater & 2,354 & & & & \\
\hline Sponges (Tethya spp.) & 648 & & & & \\
\hline Pyura stolonifera & 296 & & & & \\
\hline Others & 1,857 & & & & \\
\hline Sub-total & 5,155 & 5,825 & 30,930 & 62,891 & 26,033 \\
\hline \multicolumn{6}{|l|}{ Large carnivores } \\
\hline Jasus Ialandii & 738 & & & & \\
\hline Anemones & 199 & & & & \\
\hline Pachymetopon blochii & 506 & & & & \\
\hline Others & 91 & & & & \\
\hline Sub-total & 1,579 & 632 & 411 & 3,160 & 1,264 \\
\hline \multicolumn{6}{|l|}{ Small carnivores } \\
\hline Cirolana imposita & 149 & 826 & 648 & 4,131 & 289 \\
\hline Total & 7,183 & 7,595 & 33,072 & 74,832 & 29,174 \\
\hline
\end{tabular}

consumption and faecal production by this bivalve, which dominates parts of the kelp bed community. The average natural concentration of suspended particles in the kelp bed is $2.7 \mathrm{mg} \mathrm{l}^{-1}$ (Field et al., 1980a). This is equivalent in mass to the optimal ration level of $16 \times 10^{6}$ Dunaliella cells $\mathrm{l}^{-1}$ and yields a population respiration for $A$. ater of $14,103 \mathrm{~kJ} \mathrm{~m}^{-2} \mathrm{yr}^{-1}$ from a standing stock of $2,254 \mathrm{~kJ} \mathrm{~m}^{-2}$ (Table 3). Population respiration for the mussel is thus $6 \times \mathrm{B}$. Griffiths and King (1979b and unpublished population density figures) have also found that production (P) by $A$. ater is $1.13 \times \mathrm{B}$.

If these figures for Aulacomya ater are also applied to the other members of the filter-feeding component, production (P) for filter feeders in the kelp bed becomes $5,155 \times 1.13=5,825 \mathrm{~kJ} \mathrm{~m}^{-2} \mathrm{yr}^{-1}$ and (R) becomes $30,930 \mathrm{~kJ} \mathrm{~m}^{-2} \mathrm{yr}^{-1}$. It is now possible to calculate the consumption of the filter-feeding component of the fauna from the sum of respiration $(\mathrm{R}=$ $6 \times \mathrm{B})$ and production $(\mathrm{P}=1.13 \times \mathrm{B})$, provided that absorption efficiency at the ration level of $2.7 \mathrm{mg} \mathrm{l}^{-1}$. recorded in the kelp bed, is known. Griffiths and King (1979a) found that mussels fed on an optimal ration of Dunaliella at $2.7 \mathrm{mg} \mathrm{l}^{-1}$ have an absorption efficiency of $20 \%$, although it is well known that absorption efficiency may increase if mussels are fed on diets including natural particulate debris (see also Kiørboe et al., 1980). With regard to other filter-feeding forms, Fitzgerald (1979) found absorption efficiency of the ascidian Pyura to be as high as $90 \%$. Little is, however, known about the absorption efficiency of other forms, particularly the sponges. A. ater comprises approximately $45 \%$ of the total filter feeders, whereas Pyura, sponges and others contribute $55 \%$ (Table 2). If the

Table 3. Standing crop and population respiration of different size classes of Aulacomya ater in an idealised kelp bed. Based on data from Griffiths and King (1979a) and calculated for an optimal ration of $16 \times 10^{6}$ cells $\mathrm{l}^{-1}$ of Dunaliella $\left(=2.7 \mathrm{mg} \mathrm{l}^{-1}\right)$, which corresponds with the mean concentration of particulate matter reported for the waters of the kelp bed by Field et al., (1980a)

\begin{tabular}{|cccc|}
\hline $\begin{array}{c}\text { Shell length } \\
(\mathrm{mm})\end{array}$ & $\begin{array}{c}\mathrm{kJ} \\
\text { individual }\end{array}$ & $\begin{array}{c}\text { Standing crop } \\
\mathrm{kJ} \mathrm{m}^{-2}\end{array}$ & $\begin{array}{c}\text { Population } \\
\text { respiration } \\
\mathrm{kJ} \mathrm{m}^{-2} \mathrm{yr}^{-1}\end{array}$ \\
\hline $0-40$ & 0.48 & 43 & 238 \\
$40-60$ & 1.20 & 313 & 11,219 \\
$60-90$ & 42.0 & 1,998 & 2,646 \\
Total & & 2,354 & 14,103 \\
\hline
\end{tabular}


value for Pyura is taken as typical of non-bivalve filter feeders, the mean absorption efficiency for the group as a whole becomes $58.5 \%$, a value which appears a reasonable one for filter feeders in general and which is similar to the $52 \%$ reported for Mytilus edulis fed on a diet of $20 \times 10^{6}$ Phaeodactylum cells $1^{-1}$ (Kiørboe et al., 1981). Consumption (C) then becomes $100 / 58.5(6$ $\times \mathrm{B}+1.13 \times \mathrm{B})=12.2 \times \mathrm{B}=62,891 \mathrm{~kJ} \mathrm{~m}^{-2} \mathrm{yr}^{-1}$ and $(F)$ is $5.05 \times B=26,033 \mathrm{~kJ} \mathrm{~m}^{-2} \mathrm{yr}^{-1}$ (Table 2).

\section{Carnivores}

Values for components of the energy budget in carnivores are rather more diffucult to calculate since, as recently shown by Shafir and Field (1980), small, relatively inconspicuous carnivores such as the isopod Cirolana imposita have a very high Production (P) compared with their biomass, whereas more obvious consumers such as the rock lobster Jasus lalandii, have a lower $\mathrm{P} / \mathrm{B}$ ratio (Table 4 ). It is therefore convenient to divide the carnivores into 2 categories comprising larger organisms such as the rock lobsters, anemones and fish, and small carnivores such as Cirolana imposita.

Production for the large carnivores is estimated at $0.4 \times$ Biomass (from Shafir and Field, 1980) or $632 \mathrm{~kJ}$ $\mathrm{m}^{-2} \mathrm{yr}^{-1}$. For the purposes of Table 2 , a $\mathrm{P} / \mathrm{C}$ ratio of $20 \%$ has been assumed from similar data for Cirolana. Consumption thus becomes $632 / 0.2=3,160 \mathrm{~kJ} \mathrm{~m}^{-2}$ $\mathrm{yr}^{-1}$ and faecal production $(\mathrm{F})=1,264 \mathrm{~kJ} \mathrm{~m}^{-2} \mathrm{yr}^{-1}$, if the absorption efficiency of the large carnivores is $60 \%$. The value of $(\mathrm{R})=411 \mathrm{~kJ} \mathrm{~m}^{-2} \mathrm{yr}^{-1}$ for large carnivores has been calculated from data for Jasus and yields an R/B ratio of only 0.26 (Humphreys, 1979) compared with 3.6 in grazers and 6 in filter feeders (Table 4). This suggests that at high trophic levels, where the availability of energy is reduced, energy dissipation through respiration may be minimised through the allometric reduction in weight-specific oxygen consumption which occurs in large consumers (see also McNeill and Lawton, 1970).

Data for small carnivores, of which the isopod Cirolana imposita is the most common in the kelp bed community, have been assembled from Shafir and Field (1980). They reported the biomass of $C$. imposita within rocky habitats only, so their figures have been adjusted for the whole kelp bed area from data on relative proportions of kelp, rocks and sand given by Velimirov et al. (1977). This yields an estimated standing stock of $149 \mathrm{~kJ} \mathrm{~m}^{-2} \mathrm{yr}^{-1}$. The value of $\mathrm{P} / \mathrm{B}=5.56$ so $\mathrm{P}=826 \mathrm{~kJ} \mathrm{~m}^{-2} \mathrm{yr}^{-1}$. Population respiration $(\mathrm{R})$ is $648 \mathrm{~kJ} \mathrm{~m}^{-2} \mathrm{yr}^{-1}$ based on $\mathrm{P} / \mathrm{R}=1.02$ and consumption (C) $4,131 \mathrm{~kJ} \mathrm{~m}^{-2} \mathrm{yr}^{-1}$ based on a P/C ratio of 0.2 (Shafir and Field, 1980). They showed that the absorption
Table 4. Values for production (P), respiration (R), consumption (C) and faecal production (F) as a function of biomass (B) for the major components of a kelp bed community. The ratio of production/consumption is shown. These rates imply linear relationships, but in fact population (P) versus population (R) is a $\log / \log$ relationship in many organisms (McNeill and Lawton, 1970; Humphreys, 1979). Comparisons between sizedependent ratios for large carnivores such as Jasus and small ones such as Cirolana are thus likely to be complicated by the allometric effects of body size

\begin{tabular}{|lccccc|}
\hline Component & P/B & R/B & C/B & F/B & P/C \\
\hline Grazers & 1.04 & 3.61 & 15.50 & 5.29 & $6.7 \%$ \\
Filter feeders & 1.13 & 6.00 & 12.18 & 5.05 & $9.3 \%$ \\
Large carnivores & 0.40 & 0.26 & 2.0 & 0.80 & $20.0 \%$ \\
Small carnivores & 5.56 & 4.36 & 27.79 & 1.95 & $20.0 \%$ \\
& & & & & \\
\hline
\end{tabular}

efficiency is as high as $93 \%$ in C. imposita, so faecal production $(F)$ is only $289 \mathrm{~kJ} \mathrm{~m}^{-2} \bar{y}^{-1}$.

In contrast to the large carnivores, therefore - partly because of their small body size - these predators have a higher $\mathrm{R} / \mathrm{B}$ ratio of as much as 4.36 . But the allometric effects of body size on weight-specific metabolic rate have been compensated by a very high consumption rate (Table 4). Energy dissipation through faeces is reduced by the maintenance of an absorption efficiency of as much as $93 \%$, which results in a high $P / R$ ratio for this animal (see also Shafir and Field, 1980). The values for Production (P), Respiration (R), Consumption (C) and Faecal production (F) as a function of Biomass (B) of each of the major components of the kelp bed community are shown in Table 4

\section{ENERGY BALANCE IN THE KELP BED COMMUNITY}

It is now possible to make some general inferences on energy flow through the kelp bed community as a whole. Despite the assumptions required to derive figures for the major trophic categories in Table 2, it seems unlikely that further refinement will substantially alter the following main conclusions:

(1) The overall primary production by kelp, understorey algae and phytoplankton components in a kelp bed community amounts to $62,190 \mathrm{~kJ} \mathrm{~m}^{-2} \mathrm{yr}^{-1}$, a value similar to that of $54,037 \mathrm{~kJ} \mathrm{~m}^{-2} \mathrm{yr}^{-1}$ produced by phytoplankton alone in a comparable area of deeper water outside the kelp bed. The overall energetic conversion efficiency from incident illumination in both cases is approximately $1.6 \%$

(2) The consumer community as a whole is dominated by filter feeders, which comprise $72 \%$ of the total standing stock and account for $77 \%$ of the production (Table 5). 
(3) Filter feeders account for $94 \%$ of the energy dissipated by the consumers through Respiration (R), compared with less than $4 \%$ in each of the other trophic groups (Table 5).

(4) Consumption (C) by the filter feeders amounts to $84 \%$ of that of the community as a whole, with only $4-6 \%$ in each of the other trophic groups (Table 5).

(5) Filter feeders account for $89 \%$ of the faecal production (F) of the community as a whole (Table 5).

It is interesting to compare the estimated total primary production in a kelp bed with the calculated requirements of all primary consumers (detritus and suspension feeders plus grazers). This comparison is presented in Table 6 . It is clear that the estimated consumption requirement of primary consumers (mainly filter feeders) is approximately in equilibrium with primary production within the kelp bed; they are estimated to require only $8 \%$ more than is produced, while their production efficiency is $10 \%$. Secondary consumers (large and small carnivores) are estimated to require some $16 \%$ more than is produced by primary consumers, an imbalance which may be attributed to the errors inherent in laboratory feeding experiments (Shafir and Field, 1980) and to the impossibility of clear trophic demarkation. As might be expected, the carnivores show higher production efficiency of some $24 \%$.

Since the filter-feeding component evidently dominates the fauna, it is of some interest to look at its food supply in more detail. A schematic flow diagram for annual production and consumption in an idealised kelp bed community is shown in Fig. 1. From the total macrophyte production of $38,204 \mathrm{~kJ} \mathrm{~m}^{-2} \mathrm{yr}^{-1}$ (Table 1), we estimate that grazers directly crop $4,650 \mathrm{~kJ} \mathrm{~m}^{-2} \mathrm{yr}^{-1}$, or $12 \%$. Much of this is 'drift weed' broken free in storms (Greenwood, 1980). Of the remaining $33,554 \mathrm{~kJ} \mathrm{~m}^{-2} \mathrm{yr}^{-1}$ some $30 \%$ is in the form of dissolved organic matter (DOM) and $70 \%$ as particulate matter (POM), (Hatcher et al., 1977; Johnston et al., 1977; Newell et al., 1980) which is released by erosion from the frond tips. Thus filter feeders have available to them phytoplankton and particulate detritus, together comprising some $47,473 \mathrm{~kJ} \mathrm{~m}^{-2} \mathrm{yr}^{-1}$
Table 6. Trophic balances and ecological efficiencies in a typical kelp bed community from the west coast of Cape Peninsula. Primary producers include macrophytes and phytoplankton. Primary consumers include suspension and detritus feeders plus grazers; secondary consumers include both large and small carnivores. Compiled from Tables 1 and 2

\begin{tabular}{|lcrc|}
\hline Component & $\begin{array}{c}\text { Consump- } \\
\text { tion } \\
\left(\mathrm{kJ} \mathrm{m}^{-2} \mathrm{yr}^{-1}\right)\end{array}$ & $\begin{array}{c}\text { Production } \\
\left(\mathrm{kJ} \mathrm{m}^{-2} \mathrm{yr}^{-1}\right)\end{array}$ & $\begin{array}{c}\text { Net pro- } \\
\text { duction } \\
\text { efficiency } \\
(\%)\end{array}$ \\
\hline Photosynthetically & - & $3,608,000$ & - \\
active radiation & - & 62,190 & $1.7 \%$ \\
Primary producers & - & 6,137 & $9.9 \%$ \\
Primary consumers & 67,541 & 1,458 & $23.8 \%$ \\
Secondary & 7,291 & & \\
consumers & & & \\
\hline
\end{tabular}

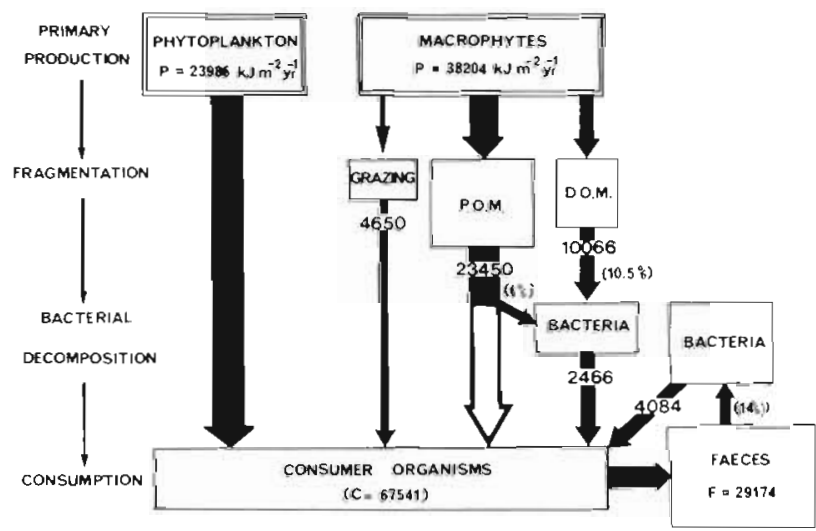

Fig. 1. Simplified energy flow diagram for a kelp bed on the west coast of the Cape Peninsula, South Africa. All values represent flow rates $\left(\mathrm{kJ} \mathrm{m}^{-2} \mathrm{yr}^{-1}\right)$. Percentages: proportion of energy passed to various categories; these are based on the conversion efficiencies of bacteria on different substrates. Open arrow: inferred flow from particulate organic matter direct to consumer organisms. See text for details

or $75 \%$ of their energy requirements. However, while we have some information about the rate and efficiency of conversion of POM and DOM to bacterial biomass in relatively simple experiments using kelp debris incubated in local seawater, we do not know the

Table 5. Percentage composition of the fauna of a typical kelp bed community from the west coast of Cape Peninsula, South Africa, with relative significance $(\%)$ of production $(P)$, respiration $(R)$, consumption $(C)$ and faecal production (F) in each trophic category. Compiled from Table 2

\begin{tabular}{|lrrrrr|}
\hline Component & $\begin{array}{c}\text { Standing stock } \\
\text { (B) }\end{array}$ & $\begin{array}{c}\text { Production } \\
\text { (P) }\end{array}$ & $\begin{array}{c}\text { Respiration } \\
\text { (R) }\end{array}$ & $\begin{array}{c}\text { Consumption } \\
\text { (C) }\end{array}$ & $\begin{array}{c}\text { Faeces } \\
\text { (F) }\end{array}$ \\
\hline Grazers & 4.2 & 4.1 & 3.3 & 6.2 & 5.4 \\
Filter feeders & 71.8 & 76.7 & 93.5 & 84.0 & 8.2 \\
Large carnivores & 22.0 & 8.3 & 1.2 & 5.3 & 4.3 \\
Small carnivores & 2.1 & 10.9 & 2.0 & 5.5 & 1.0 \\
\hline
\end{tabular}


proportion of POM that is converted to bacterial biomass before ingestion. Thus, if all the POM were utilised by bacteria with a carbon:carbon conversion efficiency of $6 \%$ (Stuart et al., 1981) and all the DOM were converted at a mean annual efficiency of $10.5 \%$ (Lucas et al., 1981) a total energy equivalent of $2,466 \mathrm{~kJ} \mathrm{~m}^{-2} \mathrm{yr}^{-1}$ of bacteria would be produced (Fig. 1). The faeces produced by consumers amount to $29,174 \mathrm{~kJ} \mathrm{~m}^{-2} \mathrm{yr}^{-1}$ (Table 2) and since this material is converted to bacteria with a mean carbon:carbon efficiency of $14 \%$ (Stuart et al., 1982) complete decomposition of faecal matter might yield a further $4,084 \mathrm{~kJ}$ $\mathrm{m}^{-2} \mathrm{yr}^{-1}$ of bacteria. The total energy yield from bacterial degradation of dissolved and particulate components of kelp, and from the decomposition of faeces could thus amount to $6,550 \mathrm{~kJ} \mathrm{~m}^{-2} \mathrm{yr}^{-1}$, a value which represents only $9.7 \%$ of the energetic requirements of the primary consumers (Table 6).

In reality, a major proportion of the particulate matter must enter the filter feeders directly, with undigested material entering the 'faecal loop' shown in Fig. 1. Refractory material may then be defaecated, resuspended by wave action and re-filtered, and may do this several times before being completely utilised thus accounting for the difference between the consumption requirements of the filter feeders and that actually available from absorption of the phytoplankton plus particulate debris in the water column. The rate at which faeces are colonised and converted into suitable food for filter feeders by bacteria is therefore likely to be a key process in the dynamics of the kelp bed community. In this regard, it is interesting to note that annual production of particulate matter is comprised in almost equal proportions of phytoplankton, macrophyte fragments and faecal matter (Fig. 1)

The processes of production and consumption within the kelp bed community should also be viewed in relation to the kelp bed and neighbouring ecosystems, as has been illustrated in Fig. 2. Jarman and Carter (1982) estimate that $12 \%$ of kelp biomass or $6 \%$ of kelp production is broken free in storms and it is reasonable to apply this figure to all macrophytes, $2.5 \%$ being stranded annually (Koop et al., 1982) while $3.5 \%$ is 'drift weed' which is consumed or degraded in shallow water. The upper part of the flow diagram in Fig. 2 is based on Koop et al. (1982) and Griffiths and StentonDozey (1981); it shows energy flow through a beach whose main energy input is stranded kelp. Probably, nutrient regeneration from the kelp on the strandline is fast, but bacteria themselves seem of little energetic significance as food for the subtidal kelp bed community.

This highlights the twin roles of bacteria in the system. In degrading detritus the bacteria themselves become available as food to consumers, but because of

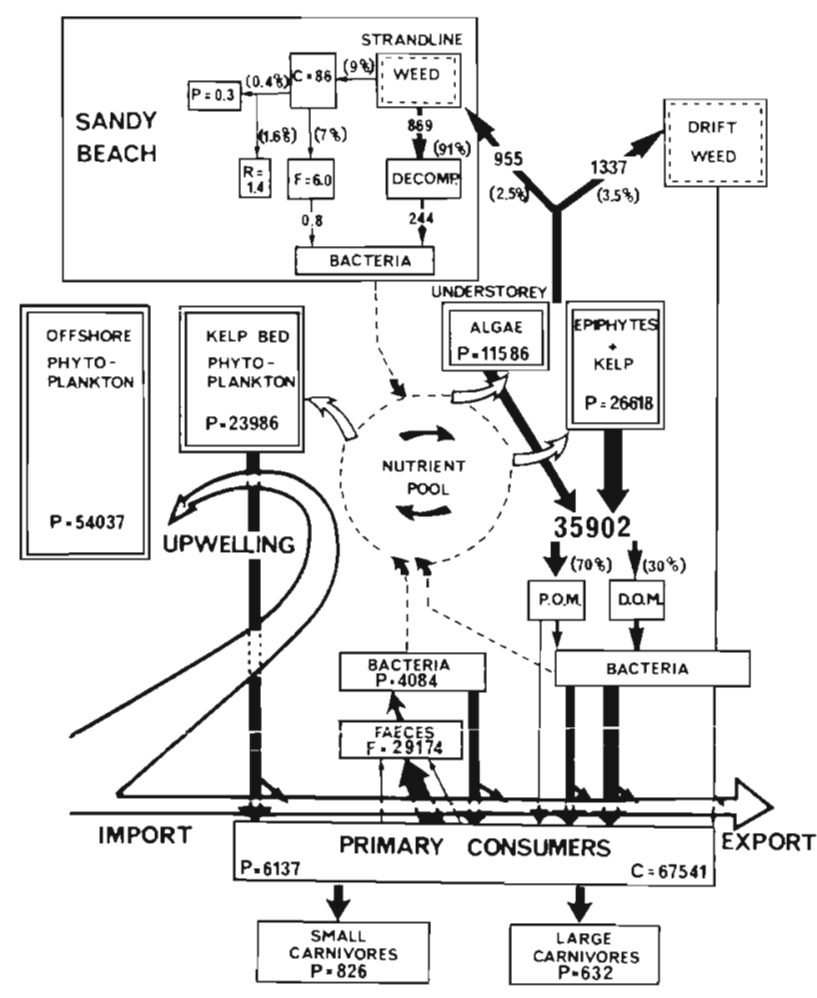

Fig. 2. Energy flow and nutrient cycling in a kelp bed and adjacent ecosystems on the west coast of the Cape Peninsula. South Africa. Primary producers inside the kelp bed are kelps and their epiphytes, phytoplankton and understorey macrophytes, with greater primary production by phytoplankton in deeper water beyond the kelp beds. Energy flow is indicated by solid arrows, nutrients by broken arrows and upwelling currents by shaded arrows. All values are energy flow rates $\left(\mathrm{kJ} \mathrm{m}^{-2} \mathrm{yr}^{-1}\right)$, with some values of production (P), consumption (C), respiration (R), and faeces $(F)$. Percentages: proportion of energy passed from one compartment to another. The nutrient pool is replenished by bacterial activity and by upwelling. See text for details

the losses incurred at 6 to $14 \%$ efficiencies, their energetic value is small even though their protein, and consequently their nutritional value, may be high compared with that of seaweeds (Mann, 1972). Concurrently with degradation of detritus, nutrients are released by the activity of bacteria (indicated by broken lines in Fig. 2). The energetics of the kelp bed thus appear to be dependent primarily on rapid mineralisation of the fragmentation products of seaweed and of faeces by bacteria which are responsible for recycling nutrients necessary to sustain primary production. The nutrient pool is also supplemented by upwelling.

The movement of water during upwelling will also result in export of suspended and dissolved material from the kelp bed to areas offshore. This is likely to be most marked during heavy wave action when detritus is resuspended and most fragmentation occurs (Field et al., 1980a). Relaxation of upwelling, or downwelling 
with onshore winds, however, results in transport of offshore plankton blooms into the kelp bed and since offshore primary production is of the same order as occurs in kelp beds (Fig. 2), it is likely that imports and exports are balanced.

Acknowledgements. We thank our colleagues at the University of Cape Town and the Sea Fisheries Institute, upon whose research (cited herein) this synthesis is based. We are grateful to $K$. Koop for commenting on the manuscript and to $S$. Tolosana for help in preparing it. Our thanks are also due to K. H. Mann who helped initiate the research programme and criticised the manuscript. The work was supported by the South African National Committee for Oceanographic Research.

\section{LITERATURE CITED}

Alexander, S. K. (1976). Relationship of macrophyte detritus to the salt marsh periwinkle, Littorina irrorata Say. Ph. D. thesis, Louisiana State University, Baton Rouge

Allen, J. C., Griffiths, C. L. (1981). The fauna and flora of a kelp bed canopy. S. Afr. J. Zool. 16: 80-84

Baker, J. H., Bradnam, L. A. (1976). The role of bacteria in the nutrition of aquatic detritovores. Oecologia (Berl.) 24: 95-104

Berrie, A. D. (1976). Detritus, micro-organisms and animals in fresh water. In: Anderson, J. M., Macfadyen, A. (eds.) The role of terrestrial and aquatic organisms in decomposition processes. Blackwell Scientific Publications, Oxford, pp 323-338

Borchers, P., Field, J. G. (1981). The effect of kelp shading on phytoplankton production. Botanica Marina 24: 89-91

Brown, P. C. (1980). Phytoplankton production studies in the coastal waters off the Cape Peninsula, South Africa. M. Sc. thesis, University Cape Town (1981)

Brown, P. C. (1981). Pelagic phytoplankton, primary production and nutrient supply in the southern Benguela region. OTrans. R. Soc. S. Afr., in press

Calow, P. (1975). The feeding strategies of two freshwater gastropods, Ancylus fluviatilis Mull and Planorbis contortus Linn. (Pulmonata) in terms of ingestion rates and absorption efficiencies. Oecologia (Berl.) 20: 33-49

Calow, P., Fletcher, C. R. (1972). A new radiotracer technique involving ${ }^{14} \mathrm{C}$ and ${ }^{51} \mathrm{Cr}$, for estimating the assimilation efficiencies of aquatic, primary consumers. Oecologia (Berl.) 9: 155-170

Cammen, L. M. (1980a). Ingestion rate: an empirical model for aquatic deposit feeders and detritivores. Oecologia (Berl.) 44: 303-310

Cammen, L. M. (1980b). The significance of microbial carbon in the nutrition of the deposit feeding polychaete Nereis succinea. Mar. Biol. 61: 9-20

Cammen, L. M., Rublee, P., Hobbie, J. E. (1978). The significance of microbial carbon in the nutrition of the polychaete Nereis succinea and other aquatic deposit feeders. Sea Grant Pub. UNC-SG-78-12, North Carolina State University, Raleigh

Carter, R. (1982). Phytoplankton biomass and production in a southern Benguela kelp bed system. Mar. Ecol. Prog. Ser. 8: 9-14

Chua, K. E., Brinkhurst, R. O. (1973). Bacteria as potential nutritional resources for three sympatric species of tubificid oligochaetes. In: Stevenson, L. H., Colwell, R. R. (eds.) Estuarine microbial ecology. University South Carolina Press, pp. 513-517

Dale, N. G. (1972), Bacteria in intertidal sediments: factors related to their distribution. Limnol. Oceanogr. 19: 509-518

Darnell, R. M. (1967). Organic detritus in relation to the estuarine ecosystem. In: Lauff, G. H. (ed.) Estuaries. Publs Am. Ass. Advant Sci, pp. 374-375

Dieckmann, G. S. (1978). Aspects of growth and production of Laminaria pallida (Grev.) J. Ag. off the Cape Peninsula. M. Sc. thesis, University Cape Town

Dieckmann, G. S. (1980). Aspects of the ecology of Laminaria pallida (Grev.) J. Ag. off the Cape Peninsula (South Africa). I. Seasonal growth. Botanica Mar. 23: 579-585

Elakova, L. A. (1972). Distribution of cellulases and chitinases in marine invertebrates. Comp. Biochem. Physiol. 43: $67-70$

Fenchel, T. (1970). Studies on the decomposition of organic detritus derived from the turtle grass Thalassia testudinum. Limnol. Oceanogr. 15: 14-20

Fenchel, T. (1972). Aspects of decomposer food chains in marine benthos. Verh. dt. zool. Ges. 65: 14-22

Field, J. G., Jarman, N. G., Dieckmann, G. S., Griffiths, C. L., Velimirov, B., Zoutendyk, P. (1977). Sun, waves, seaweed and lobsters: the dynamics of a west coast kelp bed. S. Afr J. Sci. 73: 7-10

Field, J. G., Griffiths, C. L., Linley, E. A., Carter, R. A., Zoutendyk, P. (1980a). Upwelling in a nearshore marine ecosystem and its biological implications. Estuar. coast. mar Sci. 11: 133-150

Field, J. G., Griffiths, C. L., Griffiths, R. J., Jarman, N., Zoutendyk, P., Velimirov, B., Bowes, A. (1980b). Variation in structure and biomass of kelp communities along the south west Cape coast. Trans. R. Soc. S. Afr. 44: 145-203

Fitzgerald, B. (1979). A preliminary investigation of the filtration rates of Pyura stolonifera (Heller) under laboratory conditions. Unpubl. B. Sc. (Hons) project, Zoology Dept., University Cape Town

Foster, J. R. M., Gabbott, P. A. (1971). The assimilation of nutrient from compound diets by the prawns Palaemon serratus and Pandalus platyceros. J. mar. biol. Ass. U.K. 51: 943-961

Greenwood, P. J. (1980). Growth, respiration and tentative energy budgets for two populations of the sea urchin Parechinus angulosus (Leske). Estuar. coast. mar. Sci. 10: 347-367

Griffiths, C. L., King, J. A. (1979a). Some relationships between size, food availability and energy balance in the ribbed mussel Aulacomya ater. Mar. Biol. 51: 141-149

Griffiths, C. L., King, J. A. (1979b). Energy expended on growth and gonad output in the ribbed mussel Aulacomya ater. Mar. Biol. 53: 217-222

Griffiths, C. L., Stenton-Dozey, J. (1981). The fauna and rate of degradation of stranded kelp. Estuar. Coast. Shelf Sci. 12: 645-655

Hargrave, B. T. (1970). The utilisation of benthic microflora by Hyalella azteca (Amphipoda). J. Anim. Ecol. 39: 427-437

Hargrave, B. T. (1976). The central role of invertebrate faeces in sediment decomposition. In: Anderson, J. M., Macfadyen, A. (ed.) The role of terrestrial and aquatic organisms in decomposition processes. Blackwell, Oxford, pp. 301-321

Hatcher, B. G., Chapman, A. R. O., Mann, K. H. (1977). An annual carbon budget for the kelp Laminaria longicruris. Mar. Biol. 44: 85-96

Humphreys, W. F. (1979). Production and respiration in animal populations. J. Anim. Ecol. 48: 427-454 
Jarman, N. G., Carter, R. A. (1982). The primary producers of the inshore regions of the Benguela. Trans. R. Soc. S. Afr., in press

Jensen, K. T., Siegismund, M. R. (1980). The importance of diatoms and bacteria in the diet of Hydrobia species. Ophelia 19 (Suppl.): 193-199

Johnson., C. S., Jones, R. G., Hunt, R. D. (1977). A seasonal carbon budget for a laminarian population in a Scottish sea loch. Helgoländer wiss. Meeresunters. 30: 527-545

Kepkay, P. E., Novitsky, J. A. (1980). Microbial control of organic carbon in marine sediments: coupled chemoautotrophy and heterotrophy. Mar. Biol. 55: 261-286

Kiørboe, T., Møhlenberg, F., Nøhr, O. (1980). Feeding, particle selection and carbon absorption in Mytilus edulis in different mixtures of algae and resuspended bottom material. Ophelia 19: 193-205

Kiørboe, T., Mohlenberg, F., Nøhr, O. (1981). Effect of suspended bottom material on growth and energetics in Mytilus edulis. Mar. Biol. 61: 283-288

Kofoed, L. H. (1975a). The feeding biology of Hydrobia ventrosa (Montagu) 1. The assimilation of different components of the food. J. exp. mar Biol. Ecol. 19: 233-241

Koop, K., Newell, R. C., Lucas, M. I. (1982). Biodegradation and carbon flow based on kelp (Ecklonia maxima) debris in a sandy beach microcosm. Mar. Ecol. Prog. Ser. 7: 315-326

Kostalos, M. S. (1971). A study of the detritus pathway: the role of detritus and the associated microbiota in the nutrition of Gammarus minus Say (Amphipoda Gammaridae). $\mathrm{Ph}$. D. thesis, University of Pittsburgh

Kristensen, J. H. (1972). Carbohydrases of some marine invertebrates with notes on their food and on the natural occurrence of the carbohydrates studied. Mar. Biol. 14: 130-142

Lewis, D. B., Whitney, P. J. (1968). Cellulase in Nereis virens. Nature, Lond. 220: 603-604

Linley, E. A. S., Newell, R. C. (1981). Microheterotrophic communities associated with the degradation of kelp debris. Proc. 15th Europ. Mar. Biol. Symp. Kieler Meeresforsch. 5: 345-355

Linley, E. A. S., Newell, R. C., Bosma, S. A. (1981). Heterotrophic utilisation of mucilage released during fragmentation of kelp (Ecklonia maxima and Laminaria pallida). I. Development of microbial communities associated with the degradation of kelp mucilage. Mar. Ecol. Prog. Ser. 4: $31-41$

Lopez, G. R., Levinton, J. S., Slobodkin, L. B. (1977). The effect of grazing by the detritivore Orchestia grillus on Spartina litter and its associated microbial community. Oecologia (Berl.) 30: 111-127

Lucas, M. I., Newell, R. C., Velimirov, B. (1981). Heterotrophic utilisation of mucilage released during fragmentation of kelp (Ecklonia maxima and Laminaria pallida). II. Differential utilisation of dissolved organic components from kelp mucilage. Mar. Ecol. Prog. Ser. 4: 43-55

Mann, K. H. (1972). Macrophyte production and detritus food chains in coastal waters. Mem. 1st. Ital. Idrobiol. 29 (Supp1.): 353-383

Mann, K. H. (1973). Seaweeds: their productivity and strategy for growth. Science, N.Y. 182; 975-981

Mann, K. H., Jarman, N. G., Dieckmann, G. S. (1979). Development of a method for measuring the productivity of Ecklonia maxima (Osbeck) Papenf. Trans. R. Soc. S. Afr 44: $27-42$

McNeill, S., Lawton, J. M. (1970). Annual production and respiration in animal populations. Nature, Lond. 225: $472-474$
Mills, E. L. (1975). Benthic organisms and the structure of marine ecosystems. J. Fish. Res. Bd Can. 32: 1657-1663

Mills, E. L., Foumier, R. O. (1979). Fish production and the marine ecosystems of the Scotian Shelf, Eastern Canada. Mar. Biol. 54: 101-108

Moriarty, D. J. W. (1976). Quantitative studies on bacteria and algae in the food of the mullet Mugil cephalus L. and the prawn Metapenaeus bennettae (Racek and Dall\}. J. exp. mar. Biol. Ecol. 22: 131-143

Newell, R. C. (1965). The role of detritus in the nutrition of two marine deposit feeders, the prosobranch Hydrobia ulvae and the bivalve Macoma balthica. Proc. zool. Soc. Lond. 144: 25-45

Newell, R. C. (1982). The role of decomposers in the nearshore region of the west coast. Trans. R. Soc. S. Afr. (in press)

Newell, R. C., Lucas, M. I. (1981). The quantitative significance of dissolved and particulate organic matter released during fragmentation of kelp in coastal waters. Proc. 15th Europ. Mar Biol. Symp. Kieler Meeresforsch. 5: 356-369

Newell, R. C., Lucas, M. I., Velimirov, B., Seiderer, L. J. (1980). Quantitative significance of dissolved organic losses following fragmentation of kelp (Ecklonia maxima and Laminaria pallida). Mar. Ecol. Prog. Ser. 2: 45-59

Odum, W. E., Heald, E. J. (1973). The detritus-based food web on an estuarine mangrove community. In: Cronin, L. E. (ed.) Estuarine research, Vol. 1. Academic Press, New York, pp. 265-286

Odum, W. E., Zieman, J. C., Heald, E. J. (1973). The importance of vascular plant detritus to estuaries. In: Chabreck, R. H. (ed.) Proceedings of the coastal marsh and estuary symposium. Louisiana State University, Div. of Continuing Education

Platt, T., Irwin, B. (1973). Caloric content of phytoplankton. Limnol. Oceanogr. 18: 306-309

Ryther, J. H. (1969). Photosynthesis and fish production in the sea. Science, N.Y. 166: 72-76

Shafir, A., Field, J. G. (1980). Importance of a small carnivorous isopod in energy transfer. Mar. Ecol. Prog. Ser. 3: 203-215

Sorokin, Y. I. (1978). Microbial production in the coral-reef community. Arch. Hydrobiol. 83: 281-323

Steele, J. H. (1974). The structure of marine ecosystems, Harvard University Press, Cambridge, Mass.

Stuart, V., Lucas, M. I., Newell, R. C. (1981). Heterotrophic utilisation of particulate matter from the kelp Laminaria pallida. Mar Ecol. Prog. Ser. 4: 337-348

Stuart, V., Newell, R. C., Lucas, M. I. (1982). Conversion of kelp debris and faecal material from the musseI Aulacomya ater by marine micro-organisms. Mar. Ecol. Prog. Ser. $7: 47-57$

Taghon, C. L., Self, R. F. L., Jumars, P. A. (1978). Predicting particle selection by deposit feeders: a model and its implications. Limnol. Oceanogr. 23: 752-759

Teal, J. M. (1962). Energy flow in the salt marsh ecosystem of Georgia. Ecology 43: 614 624

Velimirov, B., Field, J., Griffiths, C. L., Zoutendyk, P. (1977) The ecology of kelp bed communities in the Benguela upwelling system. Analysis of biomass and spatial distribution. Helgoländer wiss. Meeresunters. 30: 495-518

Wetzel, R. L. (1975). An experimental-radiotracer study of detrital carbon utilisation in a Georgia salt marsh. Ph. D. thesis, University of Georgia

Wetzel, R. L. (1977). Carbon resources of a benthic salt marsh invertebrate Nassarius obsoletus Say (Mollusca: Nassariidae). In: Wiley, M. (ed.) Estuarine processes, Vol. 2 Academic Press, New York, pp. 293-308 
Yingst, J. Y (1976). The utilisation of organic matter in shallow marine sediments by an epibenthic deposit-feeding holothurian. J. exp. mar. Biol. Ecol. 23: 55-69

Yokoe, Y., Yasamasu, I. (1964). The distribution of cellulase in invertebrates. Comp. Biochem. Physiol. 13: 323-338
Zhukhova, A. I. (1963). On the quantitative significance of micro-organisms in the nutrition of aquatic invertebrates. In: Oppenheimer, C. H. (ed.) Marine microbiology. Thomas, Springfield, Ill., pp. 699-710

This review was submitted to the editor; it was accepted for printing on December 12, 1981 
